\title{
На путях к федеративным Георгиевским договорам 1783 и 1802 гг.: мусульманские общества и владения Дагестана в арабоязычной дипломатической переписке и соглашениях с Картли-Кахети и Российской империей XVIII в.*
}

4 августа 2013 г. исполнилось 230 лет со дня заключения Георгиевского трактата между Российской империей и Картли-Кахетинским царством Ираклия II в крепости Георгиевск на Северном Кавказе. Это соглашение оформило протекторат России над Закавказьем и Восточным Кавказом и начало превращения горцев-мусульман региона в российских подданных. Заключенный в той же крепости в декабре 1802 г. новый договор создавал на Восточном Кавказе федеративный военно-политический и экономический союз мусульманских политических образований под властью России с целью «водворить мир и тишину между горскими владельцами, прекратить между ними самоуправство и доставить взаимную свободу торговли». История складывания подобных федеративных отношений уходит корнями в 17401760-е гг., о чем свидетельствуют сохранившиеся в российских архивах периодически возобновлявшиеся договоры между наследными правителями и военными предводителями ополчений горцев Дагестана с царями Картли и Кахети и военными комендантами Российской империи.

В то время как на северо-западе Кавказского края империя переходила к крупномасштабному строительству укрепленной границы империи - так называемой Кавказской линии от моря до моря, сопровождавшемуся массовыми переселениями горцев и казаков, ка-

\footnotetext{
* | Введение, публикация и комментарии В.О. Бобровникова при участии И.А. Каяева. Переводы В.О. Бобровникова, Ф. Бадерхана, К.Г. Халикова.
} 
рательными экспедициями против непокорных соседей, на востоке региона и в Закавказье отношения между имперскими военными властями еще вписывались в более осторожную систему отношений, удачно названную американским историком Шоном Поллоком «империей по приглашению» [Pollock, 2006]. Здесь территории, присоединенные к России в XVIII — первой половине XIX в., на первых порах сохранили свои границы и местных правителей, если те были лояльны империи. Российская сторона не вмешивалась во внутренние дела горцев, оставляя управление ими в руках местной военной знати и сельских старшин. Федеративные договоры Российской империи с мусульманскими правителями Северного Кавказа XVIII - начала XIX в. признавали экстерриториальность права обеих сторон - как российского имперского, так местного обычного (адат) и исламского (шариат). В русских крепостях горцы должны были подчиняться российским законам, а русские купцы и военные, оказывавшиеся в горских селениях, уважать местные обычаи [подробнее об этом см. в нашей работе: Северный Кавказ в составе Российской империи, 2007. С. 50-52, 61].

Горское общество этой эпохи имело ярко выраженный военный характер. Полноправным членом общества мог быть лишь воин. Боеспособные свободные мужчины составляли сельское ополчение, охватывавшее всех свободных горцев и потому насчитывавшее порой десятки тысяч воинов. В любую минуту горская община могла превратиться в военный отряд, способный сокрушить врага. Понимание общества как войска отразилось в исторической социально-правовой лексике горцев. Недаром во многих кавказских и картвельских языках понятия «народ», «община», «союз общин» служат синонимами для слова «ополчение» (авар. бо, дарг. хуреба, анд. яз. иха, груз. эри). Организация политической власти и общества на Восточном Кавказе XVIII в., по верному замечанию петербургских этнографов Л.И. Лаврова и Ю.Ю. Карпова, имела традиционно «вертикальный» характер [Лавров, 1982. С. 148; Карпов, 2001. С. 191]. Чем ниже жил народ или общество, тем сильнее было его влияние на соседей. Местные военные элиты, а через них и политические образования Северного Кавказа традиционно связывали сложные генеалогические и политические узы. Слабые подчинялись более могущественным соседям: платили дань и выставляли ополчение в случае войн и набегов.

Горские общины объединялись в экономические и военно-политические союзы (араб. нахийа). Количество их было довольно значительно. Только в Горном Дагестане XVIII в. насчитывалось около 80 общинных конфедераций. В свою очередь, ъ конфедерации общин могли объединяться в сверхсоюзы и ханства. Русские дореволюционные авторы называли их «вольными обществами». Возникнув по причинам военно-политического и судебного характера, эти объединения имели федеративное правительство, общий свод законов (адат), единый хозяйственно-культурный организм и нередко общий «войсковой» 
язык (например, аварский болмацI). Между общинами одного союза шла борьба за власть и ресурсы. Поэтому чаще горские конфедерации были построены иерархически. Политическим центром союза становилось самое сильное селение, например Хунзах в Центральном Дагестане, служившее столицей союзов и ханов (нуцалов) Аварии. Во главе союзного ополчения мог стоять наследный хан и даже кади. В Акушинском и Андалальском обществах Нагорного Дагестана последнему принадлежала высшая исполнительная и судебная власть. Споры с соседями, дела внутреннего управления и судебные иски горцев решались на так называемых народных собраниях, точнее - сельских сходах, на которых согласно местному адату присутствовали все полноправные взрослые мужчины общины. Похожие институты отмечены в XVIIIXIX вв. у хевсур, пшавов и сванов Горной Грузии. Горские ополчения из Дагестана находились на службе у царей Картли-Кахети. Вместе с тем они нередко грабили их владения в периоды ослабления царской власти и прекращения выплаты им жалованья.

Тексты Георгиевских договоров Российской империи с царями Картли-Кахети и мусульманскими владетелями Восточного Кавказа давно изданы [АКАК. Т. II. 1868. С. 1010-1012; Георгиевский трактат, 1983; Материалы по истории русско-грузинских отношений. Ч. 3. 1988; Русско-дагестанские отношения, 1988. С. 258-263], но исследование их по архивным первоисточникам продолжается. Расширенная публикация документов трактата 1783 г. готовится в этом году Росархивом в Москве. Вместе с тем вне поля зрения исследователей все еще остается немало списков соглашений и, главное, связанной с ними дипломатической переписки, дошедшей до нас как в государственных, так и в частных архивах. За последние два десятилетия автору этих строк довелось собрать внушительную коллекцию образцов дагестанской дипломатической корреспонденции на арабском языке, игравшем роль языка власти и закона для мусульман Дагестана вплоть до первой трети XX в. Мне также довелось участвовать в подготовке публикации Росархивом сборника документов по Георгиевскому трактату, куда не вошло большинство скопированных мной в собраниях Дагестана материалов.

Восполняя эту лакуну, мы решили ввести в научный оборот и опубликовать тексты и переводы 6 арабоязычных писем и соглашений по истории взаимоотношений военной мусульманской знати и союзов общин Горного Дагестана и сельской конфедерации Джара в Восточном Закавказье с царями Картли-Кахети от 1740-х годов по начало XIX в., сопроводив их подробными комментариями. Названия документов даны условно, судя по их содержанию. В состав публикации включены также 9 других, отчасти издававшихся прежде, договоров и писем на арабском, грузинском и русском языках, тексты которых неплохо поясняют исторический контекст заключения договоров. Выражаем искреннюю благодарность А.Р. Магомедову, предоставившему для перевода и публикации материалы из своего частного собрания. 


\section{1. Ответ Ираклия-хана на письмо общества Ансалта с предло- жением мира и дружбы между Картли-Кахети и дагестанцами. Без даты, вероятно, середина 1740-х годов.}

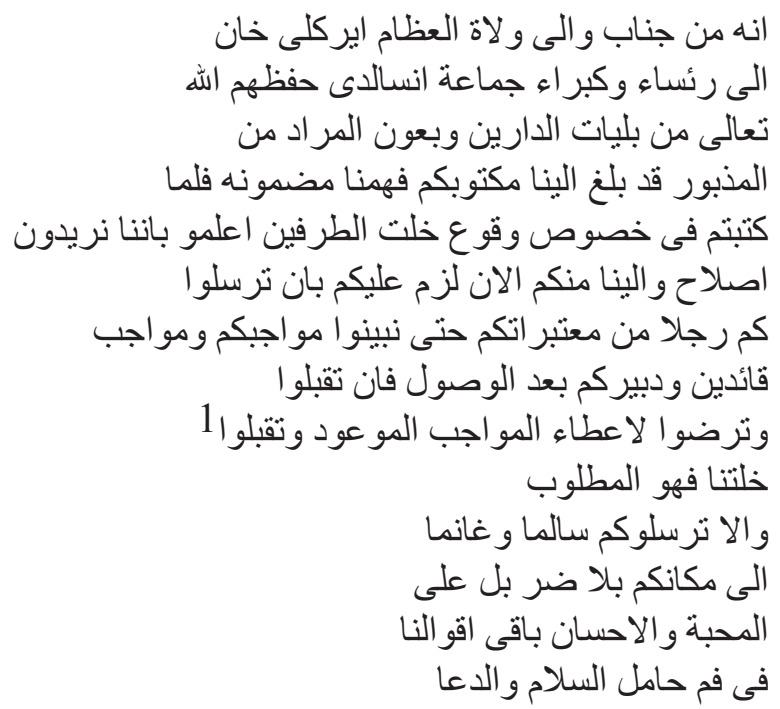

От величайшего из вали² Ираклия-хана

Старшинам и знати общества Ансалта 3 , да хранит их Всевышний Аллах от бед обоих миров и от козней с помощью желаемого!

До нас дошло ваше письмо, и мы поняли его содержание. После того как вы писали в отношении установления дружбы между обеими сторонами, узнайте, что и мы желаем мира. Нам нужно сейчас от вас, чтобы вы отправили сколько человек [,сколько] сочтете нужным, чтобы после их прибытия нам стало ясно, что нужно вам и что требуется 4 вашим предводителям и кади (дибup $\left.{ }^{5}\right)$. Если вы примете это, то будете довольны предложением необходимого свидания. Так принимайте нашу дружбу, ведь ее ищут. И мы отправим вас домой живыми и здо-

1 | Текст письма имеет спиралевидную форму. Согласно местной арабографичной традиции не уместившиеся на листе его последние 4 строки в копии Инквачилава, а вероятно, и в оригинале документа были подписаны на его правом поле.

2 | Вали (араб.), зд.: правитель, наместник. Письмо следует принятым в дороссийском Дагестане нормам официальной переписки между мусульманской знатью и союзами общин. Ираклий апеллирует к своей инвеституре «вали Грузии», которой со времен Сефевидов персидские шахи наделяли покорных им царей из династии Багратидов. Этот титул уравнивал его с наиболее влиятельными мусульманскими властителями Дагестана шамхалом Тарковским и нуцалом Аварским, которые также носили тогда титул вали. 3 | Ансалта, горное аварское селение на границах Грузии, Дагестана и Чечни. B XVIII в. его община (джама'a) входила в дагестанский союз сельских общин (нахийа) Технуцал.

4 | Требования ансалтинцев, которые хотел удовлетворить Ираклий II, касались права выпаса скота и торговли на землях Кахетии. Ср. упоминания об этом ниже в документах 10, 11. Кроме того, старшины ансалтинцев наряду с верхушкой других пограничных дагестанских обществ считались на царской службе и регулярно приезжали в Тифлис за получением пенсии. По сведениям П.Г. Буткова, обобщившего сведения грузинских и российских источников, «Ираклий давал лезгинам и прочим дагестанцам ежегодно от 60 до 100 т[ысяч] рублей... За жалованием приезжали иногда до 500 человек, которые в самом Тифлисе производили всякие наглости и убийства безнаказанно; ибо царь боялся их раздражать чтоб не охладить в них готовности на внешнюю для него службу». См.: Бутков, 1869. Ч. II. С. 118-119.

5 | Аварцы до сих пор называют имама мечети и шариатского судью дибиром (из перс., букв. «секретарь, писец»). 
ровыми, без причинения вреда, но с любовью и милостиво. Остальное [вы услышите] из уст подателя этого письма, аминь!

Оттиск арабской печати с именем Ираклий и датой 1156/1743-44 г.

[Скопировано М.П. Инквачилавом ${ }^{6}$ с письма

в одной из книг в библиотеке некоего Хариса с. Ансалта Андийского округа Дагестана в 1925 г. //

РФ ИИАЭ. Ф. 1. Оп. 1. Д. 426. Л. 124.]

(Перевод с арабского языка В.О. Бобровникова.)

\section{2. Письмо Ираклия-хана Картлинского Аварскому хану Мухамме- ду Нуцал-хану о прибытии в Грузию Тахмасп-хана и предложение приехать в Кахетию для возобновления военно-политического союза. Без даты, возможно, середина 1740-х годов}

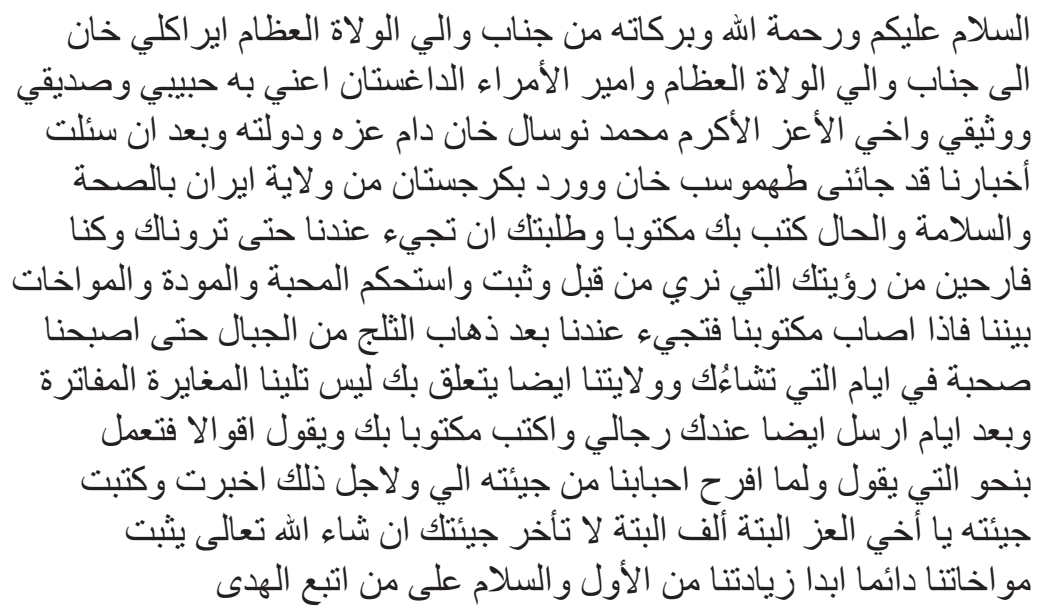

Мира, милости и благословения Всевышнего Аллаха [желает] величайший из валиев Ираклий-хан величайшему из вали, верховному правителю (букв. эмиру эмиров: амир ал-умара') Дагестана7, а именно своему любимому другу и ближайшему брату дражайшему и благороднейшему Мухаммеду нуцал-хану 8 , да не иссякнет его мощь и держава!

Если ты спросишь о наших новостях, то ко мне приехал Тахмасп$\mathrm{xaн}^{9}$, живым и здоровым вернувшись в Гурджистан 10 из области (вилайат) Иран, и написал тебе о нынешнем положении в письме. Прошу,

\footnotetext{
6 | Магомед Пирбудагович Инквачилав (ум. 1957) из с. Геничутль, сотрудник Дагестанского краеведческого музея, известный собиратель арабских древностей Дагестана в 1920-х — середине 1930-х годов. См. о нем: Козлова, 1988. С. 63-64.

7 | Ср. примеч. 1 к док. № 1.

8 | Мухаммед или Мухаммед-Мирза, сын Дугри-нуцала и отец известного в Дагестане и Грузии нуцала Умма-хана, правил Аварией с центром в с. Хунзах в Северном Дагестане в 1741-1774 гг. См. о нем: Лавров, 1968. С. 168-171; Айтберов, 1986. С. $154-156$.

9 | Речь идет об известном персидском завоевателе Тахмасп-Кули-хане (1688-1747), более известном как Надир-шах, правившем в Иране в 1736-1747 гг., или, скорее, об одном из его военачальников, действовавших в 1740-е годы в Закавказье.

10 | Принятое среди мусульман Кавказа, Ирана и Османской империи название Грузии.
} 
приезжай к нам, чтобы нам с тобой свидеться. Мы были бы рады увидеть тебя, как это бывало прежде, чтобы закрепить и утвердить любовь, дружбу и братство между нами. Как получишь наше письмо и, как только с гор[ных перевалов] сойдут снега, приезжай к нам, чтобы мы стали друзьями, в те дни, когда тебе будет удобно. Наша страна (вилайатуна) также любит тебя, и мы не относимся [к тебе] вяло и холодно. Чуть позднее я еще отправлю тебе людей и напишу подробнее, а ты поступай так, как будет сказано. Он же 11 так обрадовал наших возлюбленных друзей своим приездом ко мне, что я написал и сообщил [тебе] о его приезде. Дражайший брат мой, ни в коем случае не откладывай своего приезда. Если захочет Всевышний Аллах, наше братство укрепится навечно и навсегда и возрастет по сравнению с тем, что было прежде.

Мир тому, кто следует прямым путем!

[Оригинал письма из собрания Али Каяева в частной коллекции И.А. Каяева, г. Махачкала, Дагестан.] (Перевод с арабского языка Ф. Бадерхана и В.О. Бобровникова.)

\section{3. Письмо Ираклия-хана Али-хану о службе дагестанских ополчений царям Картли-Кахетии. Без даты, возможно, вторая треть XVIII в.}

Многочисленные приветы от величайшего из валиев - Ираклия-хана нашему ближайшему другу Али-хану ${ }^{12}$, да убережет его Всевышний Аллах от бед обоих миров!

Первым нашим желанием от Господа есть твое здоровье и благополучие. Во-вторых, во время нашего путешествия мы отправили к тебе Ахали из Анцуха 13 сообщить о наших намерениях и справиться о нашей дружбе и любви. Тебе необходимо безотлагательно и проволочек как можно быстрее прибыть к нам с тремя сотнями мужей (раджул) по окончании этого месяца раджаба по дороге, по которой вы совершаете набеги. Приезжайте с запасом еды на пять дней. Если же ты не придешь, то...14. Остальное [из] наших речей ты услышишь из уст подателя этого письма, если позволит Всевышний Аллах. И привет!

[Фотокопия в собрании проф. А.Р. Магомедова, г. Махачкала, Дагестан.] (Перевод с арабского языка К.Г. Халикова и В.О. Бобровникова.)

11 | Не понятно, о ком идет речь в конце письма, возможно, об упомянутом выше Тахмасп-Кули-хане.

12 | Один из старшин сельских обществ Горного Дагестана. Возможно речь идет про старшину союза Анцух Али-хана, о котором сообщает док. № 12. См. примеч. 51.

13 | Анцух, союз из 21 селения в верховьях Аварского Койсу, входивший в конфедерацию Антльратля (авар. Анкьракь, «Семиземье») из семи союзов общин (араб. нахийа, рус. «вольные общества»). См.: Норденстам, 1958. С. 320-324.

14 | Последняя строка перед двумя завершающими письмо строками, подписанными спирально на правом поле листка, стерлась и не поддается переводу. 


\section{4. Письмо Ираклия-хана дагестанскому обществу Джурмут о во- енно-политическом союзе царя Картли-Кахетии с дагестанцами и сборе в Кахетии дагестанских ополчений. Без даты, возможно, тре- тья четверть XVIII в.}

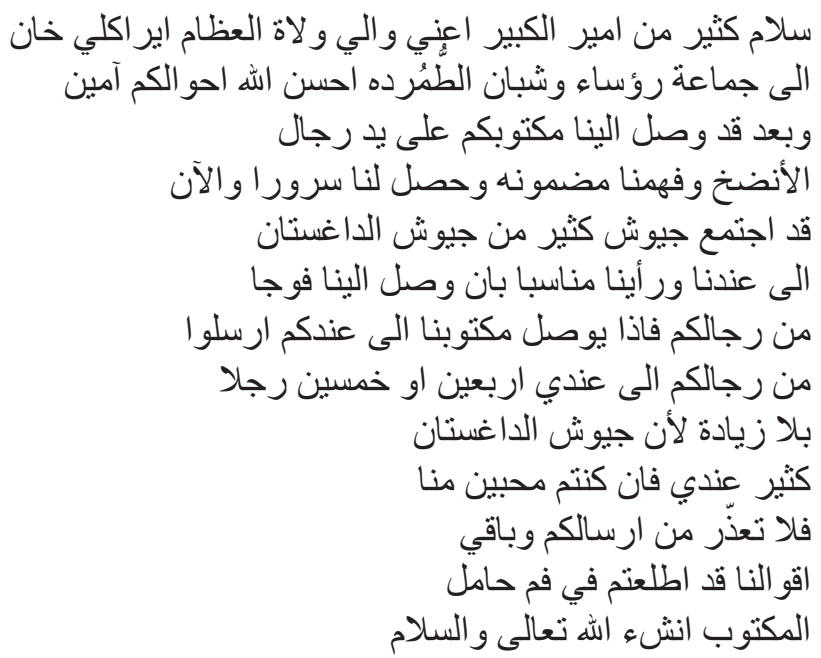

Многочисленные приветы от великого правителя, а именно величайшего из валиев Ираклия-хана обществу (джама'ат), старшинам и молодежи Джурмута (авар. ТІомурда) ${ }^{15}$, да улучшит Аллах их дела, аминь!

Ваше письмо дошло до нас из рук андихцев ${ }^{16}$. Мы поняли его содержание и обрадовались. Сейчас собрались к нам многочисленные ополчения от обществ Дагестана, и мы сочли уместным, чтобы к нам [также] пришел отряд ваших воинов (букв. мужчин — риджал). Если наше письмо дойдет до вас, пошлите из вас нам сорок-пятьдесят воинов, не больше, потому что ополчений Дагестана у нас много. Если вы Нас любите, вам будет не трудно послать [их]. Остальное [из] наших речей вы услышите из уст подателя этого письма, если позволит Всевышний Аллах.

И [еще раз] привет!

[Оригинал письма из собрания Али Каяева в частной коллекции И.А. Каяева, г. Махачкала, Дагестан.] (Перевод с арабского языка В.О. Бобровникова.)

15 | Джурмут, или Томурал (авар. ТІомурда/ТІомурал), общество (джама'ат), которое образовывали 8 селений в Джурмутской котловине по течению р. Джурмут в верховьях Аварского Койсу на территории современного Тляратинского района и Горной Грузии. Вместе с Анцухом входило в аварский союз конфедераций Семиземье (авар. Анкьракь).

16 | Общество аварского селения Андих (авар. Андых), граничившее со знаменитой конфедерацией селений Гидатля на территории современного Шамильского района Дагестана. 
5. Письмо Ираклия-хана предводителю ополчения об отражении готовящегося набега на Кахетию Ахмет-хана. Без даты, конец XVIII в., вероятно, рубеж 1770-1780-х годов

От величайшего из валиев - Ираклия-хана, наместника (вали) Гурджистана, его верному предводителю ополчений (ка’uд ал-джуйуш) Гукал-Али ${ }^{17}$ (?).

Поскольку ты всегда оставался с нами в дружбе, то узнай, что теперь Ахмет-хан 18 со своими товарищами выступили против нашей области (вилайа). И мы пишем тебе это письмо с тем, чтобы ты не приезжал к нам сейчас, но остался бы на своем месте. Если будет угодно Всевышнему Аллаху, после того как враги будут отброшены и разбиты, как это будет угодно Всевышнему Аллаху, и когда мы освободимся от этого с помощью и поддержкой Божией, то пришлем тебе письмо и пригласим тебя. А по приезде расскажем тебе, если ты приедешь, и покажем многое, и ты будешь доволен нами. Остальное ты услышишь из уст подателя этого письма.

[Фотокопия в собрании проф. А.Р. Магомедова, г. Махачкала, Дагестан.]

(Перевод с арабского языка К.Г. Халикова и В.О. Бобровникова.)

\section{6. Письмо Умма-хана Аварского ${ }^{19}$ царю Ираклию из Ахаплциха с предложением военного союза и дружбы и условиями возврата пленных, 1785 г.}

Письмо Ваше мы получили. Пишете, что тридцать три года с покойным отцом моим ${ }^{20}$ имели Вы дружбу, делали ему неоднократно благодеяния, и по кончине его оными меня удостаивали: сие есть сущая правда.

Пишете Вы также, чтобы мы отпустили пленных, взятых в Ахтале 21 . Государь отец наш, мы всегда пребывали с Вами в дружбе и, имея желание оказывать Вам наше сыновнее послушание, просили Вас беспрестанно почесть нас сыном Вашим, присылая нам приличные подарки. Но Вы нас почли не сыном Вашим, а дагестанским ${ }^{22}$ биладом ${ }^{23}$. Мы живем в Дагестане 24 . Сила сей земли Вам довольно известна, и мы вступили в Грузию сражаться, получать добычу, а не умножать Вашу славу. Если угодно Вам судить по справедливости, то должны признаться,

17 | Установить личность адресанта письма не удалось. Вероятно, речь идет об одном из дагестанских военных предводителей, возможно родом из с. Кумух, где прежде существовал квартал Гукал.

18 | Речь идет об одном из мусульманских правителей Восточного Кавказа, вероятно, об Ахмет-хане Мехтулинском.

19 | Умма-хан, правитель Аварского ханства в 1774-1800 гг.

20 | Мухаммед-Мирза сын Дугри-нуцала, правивший Аварским ханством в 1741-1774 гг. См. о нем: док. № 2.

21 Крепость в Кахетии в окрестностях Гурджаани.

22 | Подчеркнуто в оригинале документа.

23 | Билад, по объяснению опубликовавшего документ П.Г. Буткова, военный предводитель и проводник дагестанских партий, грабивших Грузию. См.: Бутков, 1869. Ч. ІІ. С. 186. Примеч. 3.

24 | Подчеркнуто в оригинале документа. 
что Вы сами подали причины к случившимся в Грузии происшествиям. Но нам неприлично требовать отчета от столь великого человека в его деяниях. Взятые пленные разделены уже войском, по дагестанскому обыкновению, и теперь нет возможности собрать оных. Впрочем, донесут Вам словесно обо всем Мирза Мегмет и Алискант 25.

Отец наш с Вами жил тридцать три года в согласии ${ }^{26}$, и потому народы дагестанские не только пребывали с Вами в мире, но и служили Вам верно 27. В противном же случае и за тысячу рублей не увидите ни одного дагестанца в войсках Ваших. И все делалось по состоявшемуся в то время между Вами и дагестанцами 28 согласию. Когда же сыновнее наше к Вам возобновится согласие, народы дагестанские ${ }^{29}$ по - прежнему повиноваться Вам станут. Теперь подумайте. Впрочем, да будет воля Вашего высочества.

[Бутков, 1869. Ч. II. С. 86-87.] (Перевод с арабского языка современный подлиннику.)

\section{7. Касающиеся Кавказа артикулы Кючук-Кайнарджийского мирно- го договора между Российской и Османской империями, заключен- ного 10 июля 1774 г.}

Поспешествующей милостью мы, Екатерина Вторая, Императрица и самодержица всероссийская: московская, киевская, владимирская, новгородская, царица казанская, царица астраханская, царица сибирская, государыня псковская и великая княгиня смоленская, княгиня эстляндская, лифляндская, карельская, тверская, югорская, пермская, вятская, болгарская и иных государыня и великая княгиня Новагорода Низовские земли, черниговская, рязанская, ростовская, ярославская, белоозерская, удорская, обдорская, кондийская и всея северные страны повелительница, и государыня Иверской земли Карталинских и Грузинских царей, и Кабардинской земли Черкасских и Горских князей 30

25 | Алискант был одним из военных предводителей войск Умма-хана и погиб в бою с российскими войсками в Закавказье в $1790-е$ годы. См.: Бутков, 1869. Ч. II. С. 186. Примеч. 4. Согласно устоявшему обыкновению дагестанской дипломатической переписки, конкретные требования и предложения Умма-хана царю Ираклию должны были передать податели письма. Известно, что, угрожая Кахетии из Ахалциха, Умма-хан требовал от Ираклия выплаты ему 10 тысяч рублей для раздачи дагестанским старшинам, находившимся в выступивших с ним в поход ополчениях, и еще себе ежегодного жалования в 10 тысяч рублей. На этих условиях Умма-хан согласен был вернуться на родину и не тревожить Кахетии. Царь последней в свою очередь соглашался выдать ему одновременно не более 10 тысяч рублей и давать впредь Умма-хану 4 тысячи рублей ежегодного содержания. См.: Бутков, 1869. Ч. II. С. $185-186$. 26 | В 1741-1774 гг.

27 | В ополчениях, выступавших по призыву царей Кахетии против ее врагов, в частности турок-османов и персов.

28 | Подчеркнуто в оригинале документа.

29 | Подчеркнуто в оригинале документа.

30 | Екатерина II унаследовала кавказскую часть императорского титула от своих предшественников на российском престоле. Большая Кабарда («государь Кабардинские земли Черкасских и Горских князей») вошла в государев титул в 1589 г. в правление царя Федора Иоанновича (1584-1598), Кахетия еще раньше - в 1587, а Картли («государь Иверския земли Карталинских и Грузинских царей») - в 1605 г. при Борисе Годунове (прав. 1598-1605). При этом к началу XVII в. кавказские территории относились к власти московских царей лишь формально, а реально не принадлежали им, и потому вошли в завершающую часть их пространного титула. См.: Каштанов, 1999. С. 181-187; Филюшкин, 2006; Пчелов, 2008. С.121-136. 
и иные наследная государыня и обладательница, объявляем сим кому о том ведать надлежит, что нынешнего тысяча семьсот семьдесят четвертого года июля в десятый день между нашим императорским величеством и его салтановым в[еличест]вом, преизрядных салтанов великим и почтеннейшим королем лепотнейшим, меккским и мединским и защитителем святого Иерусалима, королем и императором пространнейших провинций поселенных в странах европских и ассийских и на Белом и на Черном море светлейшим и державнейшим и величайшим императором, салтаном, сыном салтанов, и королем и сыном королей, салтаном Абдул Гамидом-ханом 31 , сыном салтана Ахмед-хана, по данной с обоих сторон полной власти и мочи, а именно:

с нашей стороны сиятельному и благорожденному графу Петру Румянцеву 32 , нашему генерал-фельдмаршалу, малороссийскому генералу-губернатору, Коллегии малороссийской президенту и орденов Св. апостола Андрея, Св. Георгия, Св. Александра Невского и Св. Анны кавалеру; а с его салтанова величества стороны его великому везиру и первенствующему управителю Мусун Заде Мегмет Паше, чрез взаимно назначенных от них обоих полномочных комиссаров учинен и заключен трактат вечного мира, в двадцати восьми пунктах состоящий, который в пятый на десять день того же месяца формально и принят за благо, признан и утвержден от сих обоих полной властью и мочью снабденных верховных начальников и который от слова до слова гласит как следует:

\section{ПУНКТЫ ВЕЧНОГО ПРИМИРЕНИЯ И ПОКОЯ МЕЖДУ ИМПЕРИЯМИ ВСЕРОССИЙСКОЙ И ПОРТОЙ ОТТОМАНС- КОЙ, ЗАКЛЮЧЕННЫЕ В ЛАГЕРЕ ПРИ ДЕРЕВНЕ КЮЧУК КАЙНАРЖЕ В ЧЕТЫРЕХ ЧАСАХ ОТ ГОРОДА СИЛИСТРИИ Во имя Господа Всемогущаго!}

... Арт. 3. Все татарские народы: Крымские, Буджатские, Кубанские, Едисанцы, Жамбуйлуки и Едичкулы ${ }^{33}$, без изъятия от обеих империй имеют быть признаны вольными и совершенно независимыми от всякой посторонней власти, но пребывающими под самодержавной властью собственного их хана чингисского поколения, всем татарским обществом избранного и возведенного, который да управляет ими по древним их законам и обычаям, не отдавая отчета ни в чем никакой посторонней державе; и для того ни российский двор,

31 | В 1774-1789 гг. Османской империей правил сын Ахмеда III Абдул-Хамид I.

32 | Генерал-фельдмаршал граф Петр Александрович Румянцев (1725-1796) командовал русскими войсками в войну 1768-1774 гг., окончившуюся заключением Кючук-Кайнарджийского мира. За свои победы на Балканах во время этой войны он был удостоен императрицей почетного прозвища Задунайский.

33 | Кроме крымских татар в договоре перечислены разные этнополитические группы ногайцев Большой Орды. Из них так называемые ордынцы, делившиеся на Буджакскую, Едисанскую, Едишкульскую и Джембойлукскую орды, были расселены властями Российской империи в 1771 г. на Северном Кавказе от р. Кубани до р. Еи. Кубанские ногайцы были вытеснены ими за Кубань на земли «немирных черкесов». 
ни Оттоманская Порта не имеют вступаться как в избрание и возведение помянутого хана, так и в домашние, политические, гражданские и внутренние их дела ни под каким видом, но признавать и почитать оную татарскую нацию в политическом и гражданском состоянии по примеру других держав, под собственным правлением своим состоящих, ни от кого, кроме единого Бога, не зависящих; в духовных же обрядах, как единоверные с мусульманами, в рассуждении его султанского в[еличест]ва, яко верховного калифа магометанского закона ${ }^{34}$, имеют сообразоваться правилам, законом их предписанным, без малейшего предосуждения однако ж утверждаемой для них политической и гражданской вольности. Российская империя оставит сей татарской нации, кроме крепостей Керчи и Ениколя 35 с их уездами и пристанями, которые Российская империя за собой удерживает, все города, крепости, селения, земли и пристани в Крыму и на Кубани, оружием ее приобретенные, землю, лежащую между реками Бердою и Конскими водами и Днепром, также всю землю до Польской границы, лежащую между реками Бугом и Днестром, исключая крепость Очаков с ее старым уездом, которая по-прежнему за Блистательной Портой останется, и обещается по постановлении мирного трактата и по размене оного все свои войска вывесть из их владений, а Блистательная Порта взаимно обязывается, равномерно отрешись от всякого права, какое бы оное быть ни могло, на крепости, города, жилища и на все прочее в Крыму, на Кубани и на острове Тамани лежащие, в них гарнизонов и военных людей своих никаких не иметь, уступая оные области таким образом, как российский двор уступает татарам в полное самодержавное и независимое их владение и правление. Також наиторжественнейшим образом Блистательная Порта обязывается и обещает и впредь в помянутые города, крепости, земли и жилища гарнизонов своих и всяких, какого бы звания ни были, своих людей военных в оные не вводить и там не содержать, ниже во внутри области сей сейменов или других военных людей, какого бы звания ни были, иметь, а оставить всех татар в той же полной вольности и независимости, в каковых Российская империя их оставляет.

... Арт. 22. Обе империи согласились вовсе уничтожить и предать вечному забвению все прежде бывшие между ими трактаты и конвенции, включительно Белградские, с последующими за ним конвенциями ${ }^{36}$, и никогда никакой претензии на оных не основывать, исключая только в 1700 г. между губернатором Толстым и агугским губернатором Гассаном-Пашою касательно границ Азовского уезда и учреждения

\footnotetext{
34 | Османский султан с XVI в. считался также халифом, духовным главой суннитского мусульманского мира. Халифат был упразднен в Турции уже после распада Османской империи, в 1924 г. Российская империя признала халифат османских султанов, но в 1783 г. в одностороннем порядке аннулировала этот артикул Кючук-Кайнарджийского мирного договора. 35 | Османские крепости Керчь и Ени-Кале на побережье Восточного Крыма.

36 | Согласно Белградскому миру 1739 г. между Турцией и Россией, Большая и Малая Кабарда считались независимыми, буферными землями между владениями Российской и Османской империй.
} 
кубанской границы учиненную конвенцию, которая останется непременной, так, как она была и прежде.

Арт. 23. В части Грузии и Мингрелии находящиеся крепости Богдадчик, Кутатис и Шегербань 37 , российским оружием завоеванные, будут Россией признаны принадлежащими тем, кому они издревле принадлежали, так что ежели подлинно оные города издревле или с давнего времени были под владением Блистательной Порты, то будут признаны ей принадлежащими; а по размене настоящего трактата в условленное время российские войска выйдут из помянутых провинций Грузии и Мингрелии. Блистательная же Порта с своей стороны обязывается, в сходственность с содержанием первого артикула, дозволить совершенную амнистию всем тем, которые в том краю в течение настоящей войны каким ни есть образом ее оскорбили. Торжественно и навсегда отказывается она требовать дани отроками и отроковицами и всякого рода других податей 38 , обязывается не почитать между ими никого за своих подданных кроме тех, кои издревле ей принадлежали; все замки и укрепленные места, бывшие у грузинцев и мингрельцев во владении, оставить паки под собственной их стражей и правлением, так как и не притеснять никоим образом веру, монастыри и церкви и не препятствовать поправлению старых, созиданию новых, и да не будут притесняемы какими-либо требованиями от губернатора Чилдирско$\Gamma^{39}$ и от прочих начальников и офицеров к лишению их имений. Но как помянутые народы находятся подданными Блистательной Порты, то Российская империя не имеет совсем впредь в оные вмешиваться, ниже притеснять их...

[Договоры с Востоком, 1869. С. 24, 26-27, 35-36.]

8. Из трактатавечного мира и дружбы заключенный между Империею Всероссийскою и Оттоманскою Портою в Яссах в 29 день Декабря 1791-го года чрез назначенных к тому с обеих Сторон Полномочных и подтвержденный обоюдными Государскими Ратификациями, размененными между взаимными Полномочными в Яссах в 29 день Генваря 1792 года

...Ст. V. В доказательство между обеими договаривающимися Империями искренности и дружбы, которыя, не довольствуясь единым ныне возстановлением мира и добраго согласия между ими ищут и на будущия времена утвердить оный прочным образом, отвращая со всевозможным радением все причины, могущия подать повод к спорам и

37 | Османские крепости, взятые в 1771 г. командующим русской армией в Грузии генерал-майором Г.Г. Тотлебеном: Богдатчик (Багдатчик)Б Кутаис (Кутатис), Шербан (Шегербан, Шарашан). См.: [Броневский], 1996. С. 109.

38 | Ср. документ № 5.

39 | Управлял Чилдирским или Эрзрумским вилайетом на северо-восточных границах Османской империи. Ему подчинялась часть Южной Грузии и Аджария. 
остуде, блистательная Порта обещает подтвердить вновь издаваемым фирманом данный прежде, чтоб Ахалцыкский Губернатор 40 , пограничные начальники и прочие отныне впредь ни тайно, ни явно, ни под каким видом не оскорбляли и не беспокоили земель и жителей владеемых Царем Карталинским, о чем и отправить к помянутому Ахалцыкскому Губернатору, к пограничным начальникам и к прочим с строжайшим прещением и подтверждением указы.

Статья VI. По утверждении статьею второю сего мирнаго договора, в числе прочих трактатов, акта 28 Декабря 1783 года 41 постановленнаго, касающагося до присоединения к Империи Всероссийской Крыма, Тамана и определяющаго границею в той стороне между обеими договаривающимися сторонами реку Кубань, Блистательная Порта Оттоманская, в изъявление, что она на времена будущия желает отдалить все, что мир, тишину и доброе согласие между обеими Державами возмутить может, обещает и обязуется торжественно употребить всю власть и способы к обузданию и воздержанию народов, на левом берегу реки Кубани обитающих 42 при границах ея, дабы они на пределы Всероссийской Империи набегов не чинили, никаких обид, хишничеств и разорений Российско-Императорским подданным и их селениям, жилищам и землям не приключали ни тайно, ни явно, и ни под каким видом людей в неволю не захватывали; о чем со стороны Блистательной Порты строжайщия прещения под страхом жестокаго и неизбежнаго наказания, кому следует, даны, и в тех местах после размены ратификаций на настоящий мирный договор обнародованы быть долженствуют непременно: если же и за таковым постановлением в семь трактате и чинимым подобным помянутым народам прещением, отважатся кто-либо из них учинить набег в границы Империи Всероссийской, и там приключить вред убытков или разорение, или скот, или что другое украдут, или увезут, или людей Российских в неволю захватят, в таком случае, по принесении жалобы, скорее и неотложное удовлетворение имеет быть доставлено, возвращением пограбленнаго или украденнаго, наипаче же непременным и никакой оговорке неподтвержденным отысканием и освобождением людей Российских ими убытков тем нанесенных, и примерным на границе наказанием виновных в присутствии комиссаров от пограничнаго Российскаго начальства назначаемаго; буде же, паче всякаго чаяния, таковое удовлетворение в полгода от принесения жалобы не было бы доставлено, Блистательная Порта обязуется сама все убытки заплатить из казны ея в месяц при подаче рекламации от Министра Россий-

\footnotetext{
40 | Трехбунчужный Сулейман-паша, управлявший пограничным Ахалцихским пашалыком на северо-восточных границах 0сманской империи с Грузией.

41 | 28 декабря 1783 г. Османская империя признала присоединение к России Крымского ханства и Кубани на Северо-Западном Кавказе, что было официально закреплено упомянутым здесь двусторонним османо-российским актом.

42 | Так называемые закубанские черкесы, среди которых с конца XVIII в. преобладали «немирные горцы», бежавшие от власти Российской империи за Кубань.
} 
ско-Императорскаго разумея при том, что положенныя выше наказания за нарушение спокойствия границ соседних непременно и точно исполнены быть имеют без отлагательства...

[Договоры с Востоком, 1869. С. 44-46.]

\section{9. Условия примирения общества Иланхеви с обществами Верхней Кахетии, составленные по повелению царя Ираклия II и при пос- редничестве Досифея Некресели, 1789 год}

Община Иланхеви 43 пожелала примириться с нашим Предгорьем ${ }^{44}$, сообщив об этом его величеству [Ираклию II]. Его величество же приказал тут совершить это примирение.

Иланхевские старейшины пришли к нам сюда: примирение они захотели оформить через Нас[, Досифея] 45 . И мы им в том не отказали, взяли на себя поручительство [контролировать положение дел] между нашим Предгорьем и ними. Мы взяли тут с обеих сторон [соответствующие] обязательства, заставив дать клятвенное заверение.

Люди нашей страны не должны причинять им вреда и не должны ничего отнимать [у них - иланхевцев].

Если возникнет тяжба [между жителями нашего Предгорья и иланхевцами], то пусть будет она разобрана Нами. Силою пусть никто ничего [у иланхевцев] не забирает - ни князь, ни крестьянин. Если кто задолжает что-либо, пусть [поделят] пополам; тяжба же будет разрешена Нами[, Досифеем].

«Изменой», силой и беззаконно пусть с ними[, иланхевцами,] никто не поступает; пусть они приходят, торгуют и уходят с миром.

У жителей Предгорья взяли Мы сие обязательство и заставили их поклясться, чтобы они отныне ни в чем не грешили. И у иланхевцев взяли Мы такое обязательство, чтобы отныне в стране этой «изменой» они ничего не портили, не воровали.

Если [иланхевцы] что-либо узнают о появлении войск [Дагестана] и разбойников (качах), то, как смогут, пусть сообщат.

Не примирившегося [с нами] человека пусть они сюда торговать не приводят.

Если кто-либо из их общины совершит здесь зло и затем уйдет отсюда в другую страну, то пусть [иланхевцы] не упрямятся: нанесен-

\footnotetext{
43 | Иланхеви («Ущелье [реки] Илан») - грузинское название дагестанской конфедерации Дидо-Шаитли на территории современного Цунтинского района Дагестана. Включала 5 союзов общин селений Азильта, Тлясуда, Хуитли, Кунтан, Шаитли. Ущелье как таковое было основной природно-политической формой существования горского общества в Горной Грузии, Дагестане и Чечне. Этнонимы хевсур и мохевцев восходят к понятию ущелье (груз. хеви). См.: Карпов, 2007. С. 37, 506; Дмитриев, 2009. С. 152. 44 | Общества Верхней Кахетии, пограничные с Дагестаном.

45 | Видная фигура в иерархии Грузинской православной церкви. Иланхевское соглашение неплохо показывает иерархию федеративных связей в Закавказье, роль царей Картли-Кахетии и церкви в урегулировании взаимоотношений между христианским и мусульманским населением региона, которую, начиная с Георгиевского трактата, постепенно берут на себя военные власти Российской империи.
} 
ный тем человеком ущерб пусть возместит [его] джамаат, взяв, что тут следует из хозяйства и дома этого человека.

Жители одного села - эшитцы ${ }^{46}$, через капучинского Али Ганджашвили и через иланхевца Алуба Али, помирились с нами и мы взяли с них, в качестве залога, одно крымское ружье ${ }^{47}$.

Сколько бы иланхевских сел не примирилось с нами, с каждого села должны дать в залог по одному крымскому ружью и соблюдать те условия, которые написаны выше.

Кто знает: люди [Иланхеви, положим,] не оставят свои привычки или нанесут они ущерб нашим, или убьют кого-либо, или похитят. Либо, положим, наш человек убьет их человека, то каковая плата за кровь установлена Его величеством капучинцам и дидойцам ${ }^{48}$, пусть это же возмещение и плату за кровь отдадут [иланхевцам]. Если же они нанесут ущерб нашему человеку или убьют его, или пленят, то ту же плату за кровь и возмещение пусть дадут уже они - нашим людям. На этих условиях заверили и наших людей и иланхевцев.

Кто знает: если, [положим,] раздор учинят наши люди, то пусть они отошлют [в Иланхеви] взятое ими в залог ружье и сообщат [иланхевцам], что примирение более не в силе. Таким же образом, если раздор учинят они, [иланхевцы], то пусть потребуют они свое ружье и сообщат, что примирение более не в силе.

«Изменой» ни наши люди не должны учинять раздор, ни иланхевцы. На этом условии обе стороны поклялись — как люди нашей стороны, так и иланхевцы.

Нас, Досифея Некресели, обе стороны взяли тут в качестве поручителя.

Кто нарушит эти условия, должен заплатить десять туманов 49 штрафа Его величеству царю [Ираклию II]: если наши люди нарушат, то десять туманов штрафа царю заплатят они, а если иланхевцы нарушат, то они десять туманов штрафа царю заплатят.

Октября 2, в хроникон 47750 .

Досифей.

Августа месяца 9, в [хроникон] 483. Кайхосро пожаловал к Нам, а грамоту эту принес нам Агубас-ага, сделав это при посредничестве и по слову Жабо 51.

Затем и Мы копию сего - еще одну новую грамоту о примирении, — отдали (но только касается она лишь эшитцев) Некресели.

[Гамрекели, 1991. С. 124-125.]

(Пер. с груз. В.Н. Гамрекели.)

46 | Из цезского селения Шаитли (авар. Шайикь, Эшикь) или соседнего с ним Шаури (Эшо).

47 | Кремневые крымские ружья высоко ценились в дороссийском Дагестане.

48 | Капуча, союз общин на границе северо-западного Дагестана с Верхней Кахетией. С дидойцами его связывали союзные отноше-

ния. Население обоих обществ составляли представители малочисленных цезских народов.

49 | Туман, иранская монета, равная 10 русским серебряным рублям.

50 | Чит. 312 г. Соответствует по грузинскому летоисчислению 1789 г. по юлианскому календарю (примеч. переводчика

В.Н. Гамрекели).

51 | Жабо - имя собственное, распространенное у дидойцев и капучинцев. 
10. Письмо правителя Тушетии моурав-туша и эристава Джамширбека Мухаммад-нуцалу сыну Умму-хана о союзе и службе туш-моуравов с нуцалом и правителем Картли Ираклием-ханом. Без даты, вероятно, рубеж XVIII-XIX вв.

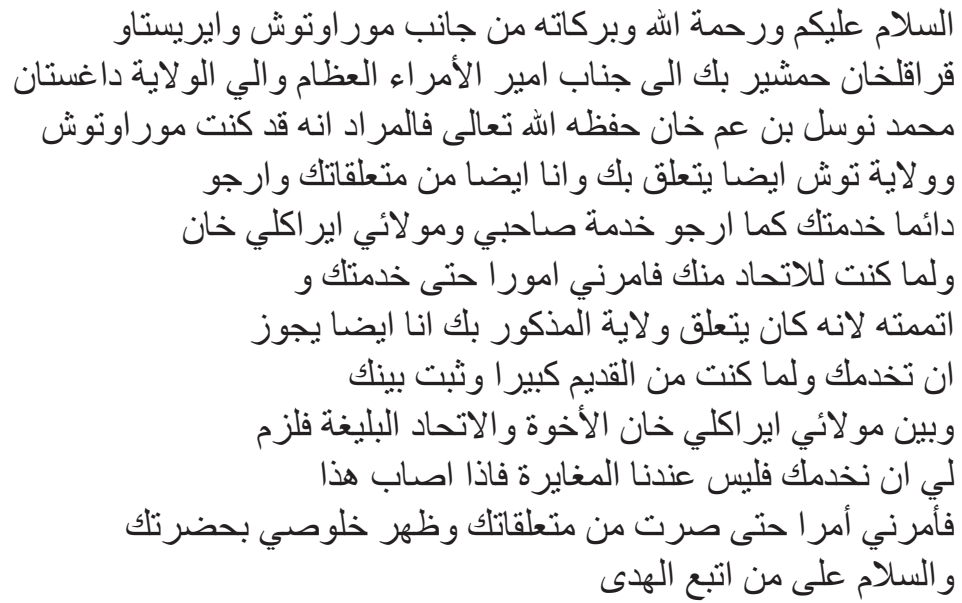

Мира, милости и благословения Всевышнего Аллаха [желает] моурав тушин и эристав 52 кара-калхан Джамшир-бек величайшему из правителей (эмиру эмиров) валиев, верховному правителю (эмиру эмиров) и вали области (вилайа) Дагестан Мухаммад-Нуцалу сыну Умма-хана, да охранит его Всевышний Аллах!

Мне желательно [сообщить тебе], что я стал туш-моуравом 53 , область же Тушетия зависит от тебя, а я также из числа твоих слуг и желаю всегда служить тебе, равно как хочу служить моему господину (сахиб) и государю (маули) Ираклию-хану. Поскольку я состою с тобой в союзе, он приказал мне служить тебе, и я это делаю, поскольку упомянутая область связана с тобой. Мне также разрешено служить тебе, так как повелось с давних времен, что между тобой и моим государем Ираклием-ханом установились братские отношения и крепкий союз. Мне должно служить тебе, и нет у нас [об этом] иного мнения. Если ты находишь это справедливым, то приказывай мне, чтобы я стал из числа твоих слуг и смог показать свою верность тебе, мой господин.

Мир тому, кто следует прямым путем!

[Оригинал письма из собрания Али Каяева

в частной коллекции И.А. Каяева, г. Махачкала, Дагестан.]

(Перевод с арабского языка В.О. Бобровникова и Ф. Бадерхана.)

52 | Моурав (груз.) - управляющий провинции в Грузии. Эристав (груз. букв. «глава народа») - титул наследной грузинской знати, возглавлявшей военно-административные области (эриставства). См.: Бутков, 1869. Ч. ІІІ. С. 340.

53 | Тущ-моурав - титул правителей области Тушетия в составе Верхней Кахетии на границе с Дагестаном. 
11. Письмо Джарских обществ к главнокомандующему на Кавказе генерал-лейтенанту К.Ф. Кноррингу о заключении между джарцами и российским правителем Грузии мира и союза, подобных тем, что они заключали прежде с Ираклий-ханом, март 1801 г.

Да будет мир над Вами и милость, и благословение Божие!

После многих поклонов и приличных приветствий от улемов, старшин и вообще всех Джарских обществ 54 к знаменитому эмиру, достославнейшему и мудрейшему вельможе великаго императора, губернатору и правителю Гурджистанскому 55 и зависящих от него городов и деревень, - да направит Вас Господь на путь истины, Аминь!

Желаем Вам благополучия и спокойствия, и объявляем Вам, что мы получили почтеннейшее Ваше письмо чрез любезнаго Вашего подданнаго, Кизикского и Карданахского 56 жителя, прочли его, поняли с начала до конца его содержание и смысл. Остальные предметы объяснил нам посланный изустно. Знай, о достославный вельможа, что союз, мир, уничтожение несогласия и примирение обеих сторон между соседями есть дело важное, желаемое обоими соседними народами. Действительно, мы всегда заключали мир и союз с Ираклий-ханом и примирялись с ним; с Вами же еще более мы желаем примирения, чем с Ираклий-ханом, но только боимся, что после мира не будем в состоянии исполнять его условия, согласно обещанию и присяге, точно так, как их требует мир; и тогда мы сделаемся виновными перед Вашими стопами. Вы вовсе не похожи на Ираклий-хана и на другаго из ханов; Вы слуга великаго падишаха. Нам не прилично поступать с Вашим падишахом иначе как верно и чистосердечно. Мир заключается обычно между равными сторонами, а падишаху может быть равен только падишах. Вот наше объяснение Вам. Остальные слова поручены для передачи Вам в точности посылаемому человеку. Да будет мир над теми, кто следует по пути благочестия 57.

[март 1801 года.]

[АКАК. Т. І. Тифлис, 1866. С. 645.] (Перевод с арабского языка современный подлиннику.)

\footnotetext{
54 | Джаро-Белоканский союз независимых сельских общин горцев-мусульман Дагестана на территории современного СевероЗападного Азербайджана. Джар постоянно тревожил набегами христиан Кахетии. По присоединении Картли-Кахетинского царства к Российской империи в марте 1803 г. усиленный российскими войсками отряд грузинской милиции под командованием генералмайора В.С. Гулякова разгромил ополчение джарцев и разорил с. Белоканы. См.: Хроника войн Джара, 1931; Петрушевский, 1934; Süleymenova, 1997.

55 | Барон Карл Федорович Кнорринг (1746-1820) в 1802-1803 гг. управлял Грузией и Астраханской губернией, представляя высшую военную и гражданскую власть на российском Кавказе как инспектор войск на Кавказской линии и командующий Кавказской армией (1801-1802). На этом посту его сменил князь Павел Дмитриевич Цицианов (1754-1806).

56 | Карданах - кахетинское селение в Алазанской долине в Восточной Грузии. Кизики - историческая область на юге Нижней Кахетии.

57 | Такого же рода письмо было прислано и от Белоканских обществ (примеч. издателя).
} 
12. Письмо главнокомандующего на Кавказе генерал-лейтенанта К.Ф. Кнорринга к Анцухскому обществу о заключении письменного соглашения в гарантию недопущения хищничеств, сохранения мира и добрососедства анцухцев с Грузией от 3 мая 1802 г.

\author{
Благодарю вас за поздравление меня с благополучным прибы-
} тием в Грузию, которое изъяснено в письме вашем, полученном мною общества вашего от почетных старшин Юсуп-Сагита, Когкочи-Бегуна и Магмат-Кабиба...

E[го] И[мператорское] $\quad$ В[еличество], мой всемилостивый Г[осударь] И[мператор], соизволив принять в могущественное управление Свое народы грузинские, высочайше повелел мне сохранять доброе расположение к соседним народам, ежели оные не будут причинять Грузии вреда. И как известно мне, что Анцухское общество 58 всегда прежде к Грузии было миролюбиво, имело сюда свои торги и пасло скот свой в границах грузинских, то желая, чтобы вы и теперь пребывали добрыми соседами к Грузии ${ }^{59}$, не производили бы ни сами в землях ея хищничеств, не делались бы другим неспокойным лезгин-

58 | Анцух - союз сельских общин в верховьях Аварского Койсу, входивший в дагестанскую конфедерацию Семиземье (авар. Анкьракь). См. о нем выше в примеч. 12 к док. № 3.

59 | Союз анцухцев с царями Кахетии предусматривал право первых в обмен на военную помощь в охране границ вести торг и пасти скот на землях Грузии. Кроме того, анцухское общество ежегодно получало от царя Ираклия жалованье на содержание своего ополчения. Вплоть до начала XIX в. анцухцы пытались строить отношения с военными властями Российской империи наподобие прежних соглашений с царем Ираклием. Выдавая после долгих переговоров генералу А.П. Ермолову грузинского царевича Александра, они заключали зимой 1817 г. свое письмо к русскому генералу требованием возобновить выплату дани:

«0тправляем к Вам нашего старшину Али-хана для заключения с Вами мира и согласия. 0 высокопочтенный эмир Ермолов! Мы будем поступать так же, как поступали с эмиром Ираклий-ханом, и мы желаем, чтобы ты также сделал то, что делал Ираклий-хан, и чтобы ты подобно ему платил нам дань и пр[очее]. Остальные слова передаст Вам податель поклона Али-хан» (Перевод с арабского 1875 г.) [АКАК. Т. VI. Ч. II. 1875. С. 32; Дубровин, 1888. С. 286].

Зная вспыльчивый характер главнокомандующего и жесткие меры, применявшиеся им к врагам во время управления Грузией и на Кавказе, можно было бы ожидать отправки к анцухцам карательной экспедиции. Однако Ермолов ограничился вежливым, хотя и жестким письмом, в котором объявлял об установлении между горскими обществами и российскими военными властями новых отношений подданства и беспрекословного подчинения военным приказам русских:

«Все просьбы ваши, присланные ко мне с Али-ханом и другими старшинами, от вас избранными, я получил. Видя же из них приносимую вами покорность российскому правительству, не мог я отказать вам в снисхождении, единственно по соболезнованию о нынешнем вашем положении, до которого вы доведены своим неблагоразумием, а еще больше потому, что мне совершенно известна неизреченная благость сердца моего великаго и всемилостивейшаго Г[осударя] И[мператора] ко всем тем, кои с искренним раскаянием прибегают к Его милосердию. Не ожидайте от меня однако никакого уважения к просьбе вашей, чтобы от российского правительства определены были вам те же дары, которыми вы пользовались прежде, служа покойному царю Ираклию, ибо теперь владычествуют здесь не цари грузинские, но могущественный всероссийский Г[осударь] И[мператор], коего власть и неодолимая сила настолько же превышает власть прежнего в Грузии правления, сколь далеко отстоит солнце от земли. Притом виновный перед своим судьей никогда не должен и не смеет предлагать каких-либо условий. Итак, анцухцы, будьте довольны, что я предаю вечному забвению проступки ваши в течение 4-х лет, коими вы навлекли на себя гнев, давая у себя убежище беглому царевичу Александу, покушавшемуся всегда на вред Грузии и охраняющих ее высокославных российских войск. Но вящшею еще к вам милостью и особенным благополучием примите то, что я, имея в руках своих всю силу, вместо праведнаго мщения дарую вам совершенное спокойствие среди ваших жилищ и, узнав о бедности, до коей вы дошли, позволяю вам свободную торговлю по всей Грузии, наравне с природными подданными России, всегда покорными власти правительства. Отныне уничтожается запрещение вам иметь с Кахетией всякое сообщение, и я дал уже приказание дозволить вам продавать свои изделия, где вы пожелаете, также покупать нужные для семейств ваших потребности и выгонять для пастьбы стада свои на плоскости, Грузии принадлежащие.

Старшины ваши приняты мной с приличным уважением. Они пользуются достаточным содержанием и коль скоро кончат дела свои, касающиеся до благосостояния их общества, то я не замедлю отправить их обратно таким образом, что они весьма будут мной довольны. Между же тем, по собственному их желанию, мне изъявленному, я отправляю к вам Чок-Али и Мамеда с сим предварительным сообщением о милости, даруемой вам российским правительством. Затем пребываю к вам усердный и доброжелательный» [АКАК. T. VI. Ч. II. 1875. C. 33]. 
цам 60 проводниками, и совершенно бы не только не допускали людей своих к воровствам и грабежам в Грузии, но чрез жилища свои никого вы из ветреных лезгинцев в Грузию не пропускали; а ежели бы случилось, что кто-либо из вас поступил вопреки сего, обязались бы все вы ответствовать за ущерб, в границах Грузии причиненный, — требую, чтобы во всем том дали вы письменное от всего общества обязательство и трех из лучших фамилий аманатов 61 , которые благопристойно содержаны будут близ ваших жилищ в городе Телаве. Я препоручил ген[ерал]-м[айору] Гулякову 62 иметь с доверенными вашими разговор и привести все вышепоказанное к доброму окончанию; и ежели вы согласны требование мое исполнить, тогда не только ни малейше не будете в опасности от победоносных войск российских, но и обрящете вящше пользы свои от добраго соседства с Грузиею.

[АКАК. Т. І. Тифлис, 1866. С. 657.]

13. Письмо главнокомандующего на Кавказе генерал-лейтенанта К.Ф. Кнорринга к обществам лезгинских деревнь Андисской, Ботлихской, Тандусской, Шодротской и Ансалдской 63 , о заключении письменного соглашения в гарантию недопущения ими хищничеств, сохранения мира и добрососедства с Грузией, от 15 мая 1802 г.

На письмо ваше, коим вы просите позволения иметь торги с Грузиею, ответствую вам ${ }^{64}$, что, поелику Е. И. В., мой всемилостивый Г[осударь] И[мператор], соизволив принять в могущественное управление Свое народы грузинские, высочайше повелел мне сохранять доброе расположение к соседним народам, ежели оные не будут причинять Грузии вреда, то не иначе могу я позволить вам производить торги, как чтобы вы согласились не только быть мирными и благонамеренными соседами к Грузии, не производили бы ни сами в землях ея хищничеств, но не делались бы и другим неспокойным лезгинцам проводниками, и, не допуская людей своих к воровствам и грабежам в Грузии, не перепус-

\footnotetext{
Следует отметить, что в урегулировании конфликта Ермолова с анцухцами немалую роль сыграло перекрытие российскими войсками перевалов и дорог, связывавших Дагестан с Кахетией, через которые лежали традиционные скотоперегонные трассы анцухцев. См.: Карпов, 2007. С. 287.

$60 \mid$ Под лезгинами, или лезгинцами, в российской этнографической номенклатуре XVIII-XIX вв. понимали всех дагестанских горцев, а не только и не столько лезгин. Зд. речь идет скорее про андо-цезские народы и близких им аварцев, проживавших в Западном Дагестане на границе с Грузией.

61 | Аманаты (араб.) - заложники были общей практикой обеспечения нерушимости международных договоров на Кавказе XVIII - первой половины XIX в.

62 | Василий Семенович Гуляков (1754-1804) - один из героев покорения Кавказа, отличившийся в боях с горцами на границе с Грузией, в частности в битве на р. Иоре, где был разбит двинувшийся на Картли-Кахетию Умма-хан Аварский. В марте 1803 г. совершил экспедицию из Грузии в Закаталы, покорив власти Российской империи Джаро-Белоканское общество, Илисуйский султанат и владения по р. Самуру. 15 января 1804 г. убит в бою с отрядом Казикумухского хана в Закатальском ущелье.

63 | Анди, Ботлих, Тандо, Шодрода, Ансалта - горные селения на границе Северо-Западного Дагестана с Грузией и Чечней. Входили в состав конфедерации Технуцал.

64 | По содержанию это письмо почти дословно повторяет текст рескрипта, отправленного за несколько дней до того Кноррингом Анцухскому обществу. См. выше документ № 8.
} 
кали бы чрез жилища свои никого из ветреных лезгинцев; ежели бы случилось, что кто-либо из вас вопреки сего поступит, обязались бы все вы письменно ответствовать за ущерб, в границах Грузии причиненный, - в удостоверение чего и должны вы дать из лучших ваших фамилий аманатов, каких я назначу, которые благопристойно содержимы будут недалеко от жилищ ваших в городе Телаве. Я препоручил ген[ерал]-м[айору] Гулякову иметь с доверенными вашими разговор и привести все вышеписанное к доброму окончанию, и если вы согласны сие требование мое исполнить, тогда не только ни малейше не будете в опасности от победоносных войск российских, но и найдете вящшия пользы свои от добраго соседства с Грузиею.

Для получения же от вас на сие ответа или, если кто отправлен будет от вас ко мне, то и для его препровождения послан к вам с сим мирза-михмандар 65 .

[АКАК. Т. І. Тифлис, 1866. С. 657.]

14. Донесение правителя Грузии П.И. Коваленского главнокомандующему на Кавказе генерал-лейтенанта К.Ф. Кноррингу о согласии Анцухского, Капучинского и Карахского обществ соблюдать добрососедские отношения и просьбе разрешить им торговлю с Грузией, 13 июля 1802 г.

Посланный от В[ашего] Пр[евосходительства] из Кахетии в горы к лезгинским народам нарочный на днях оттуда возвратился и доставил на имя мое от анцухских, капучинских и карахских народов 66 письма, в коих, изъявляя о готовности своей пребывать в мире и соседственной дружбе с обывателями здешними, просят они о позволении производить по-прежнему торговлю свою с Грузиею, для сего и отправили они уже один караван на границы; с другой стороны, здешнее купечество и ремесленники изделий, коими производилась прежде торговля с лезгинцами, чрез пресечение сея отрасли претерпевающие по оборотам своим, с пользою коммерции их и, следственно, казенною сопряженным, чувствительную расстройку, повторяя убедительнейшие свои о том представления, неотступно просят позволить лезгинам производить торг по-прежнему в Грузии.

Я, приемля во уважение обоюдные сии просьбы на предмет такого позволения, которого по здравой политике с нашей стороны всегда желать должно, но не имея, однако ж, никакого на то от в. пр. на-

65 | Мирза-михмандар - зд. секретарь, чиновник, принимающий и представляющий посольства, официальные делегации горских обществ и владельцев к российскому военному командованию Кавказского края и Грузии. Термин персидского происхождения. 66 | Анцух - союз из 21 селений в верховьях Аварского Койсу, входивший в конфедерацию Антльратля. См. о нем: примеч. XII. Капуча, союз сельских общин, пограничный Анцуху. См. о нем примеч. XXXVI. Конфедерация Карах занимала горную долину в междуречье Андийского и Кара-Койсу. Население этих обществ составлли аварцы (Карах) и цезские народы (гунзибцы в Анцухе и капучинцы в Капуча). См. о них: Алиев, Умаханов, 1999. С. 281-282. 
ставления, решился позволить впустить в пределы Грузии тот только караван лезгинский, который уже прибыл на границы, а о дальнейшем открытии сей торговли представить на разрешение в. пр., что сим и исполняю.

[АКАК. Т. І. Тифлис, 1866. С. 660; Русскодагестанские отношения, 1988. С. 256.]

15. Договор, заключенный в крепости Георгиевск между дагестанскими и азербайджанскими владетелями 26 декабря 1802 г., из рапорта князя П.Д. Цицианова Государственной коллегии иностранных дел 28 декабря 1802 г.

Во имя Всемогущаго Господа Бога!

Мы, нижеподписавшиеся уполномоченные и доверенные: превосходительного и высокостепенного Кубинского, владеющего ныне Дербентом Ших Али хана, чиновник его Медет-бек; сиятельного и превосходительного шамхала Тарковского, владетеля Буйнацкого и Дагестанского, Мегди, чиновник его [М]ирза-бек; превосходительного и высокостепенного талышинского Мир Мустафа-хана двоюродный брат его Мирза-Магомед-бек; превосходительного и высокостепенного Каракайдакской округи владетеля, уцмия Рустем-хана, чиновник его Ахмет-ага; правителя округи сей, высокостепенного Рази-хана, чиновник его Узней-бек; превосходительного и высокостепенного Табасаранской округи владетеля, кадия Рустем-хана, чиновник его Мамед бек; и высокостепенных сей же Табасаранской округи владельцев Сохраб-бек маасума, чиновник его Нур-Мамед-ага Мустафаев, и Махмуда, брата владетеля округи Табасаранской, кадия, чиновник его Ших-мулла ${ }^{67}$, — вняв гласу милосердия и благости всемилостивейшего нашего Г[осударя] И[мператора] и самодержаца всероссийского Александра Павловича, в лице высокостепенных наших ханов, сиятельного и превосходительного шамхала Тарковского и горских владельцев, в высоком подданстве и покровительстве Е[го] И[мператорскаго] В[еличества] состоящих ${ }^{68}$, по предложению, нам сделанному всероссийских войск ген[ерал]-

67 | Федеративный договор, заключенный в Георгиевске, подписали 7 мусульманских владельцев приморского Дагестана и Талышский хан. Это Махди сын Баммата, шамхал Тарковский в 1797-1830 гг.; сын Фет Али (Фатх-Али) хана Кубинского и Дербентского Ших (Шайх) Али-хан, правивший в 1790-1796, 1797-1800, 1803-1806 гг. Кроме них в союз вошли Мир Мустафа-хан Талышинский (ум. 1814), чье ханство находилось на юго-востоке Азербайджана; преемник Амир-Хамзы Рустем-хан уцмий Кайтагский (прав.1796-1800 и 1801-1804 гг.); владелец Кара-Кайтага Рази-бек; Табасаранский кади Рустам-хан; Табасаранский майсум Сохрод-бек и независимый владелец Табасаранский Махмуд-бек. См.: Бутков, 1869. Ч. II. С. 375, 408, 454; [Броневский] 1996. С. 148-149; Лавров, 1968. С. 157-158, 160-161.

68 | Участники Георгиевского договора 1802 г. уже состояли в российском подданстве и находились на русской службе. Большинство из них получали из казны приличные оклады, предназначенные для содержания при их владениях горских ополчений. Махди шамхал Тарковский имел чин генерал-лейтенанта российской армии и получал 6000 рублей в год, Рустем-хан уцмий Кайтагский - 2000 рублей, Рази-бек владелец Кара-Кайтагский - 600 рублей, Рустем-хан кади Табасаранский - 1500 рублей, майсум Сохрод-бек и табасаранский владелец Махмут-бек - по 450 рублей. Ших Али-хан Дебентский и Мир Мустафа-хан Талышинский жалованья из России не получали. 
лейтенантом, Кавказской инспекции по инфантерии инспектором, главноуправляющим Грузиею, Астраханским военным губернатором, начальствующим и по гражданской в губернии сей части, управляющим пограничными Кавказского края делами и разных орденов кавалером, кн[язем] Павлом Цициановым ${ }^{69}$, что Е[го] И[мператорское] В[еличество] состоящих, из врожденного ко благу человечества побуждения, взирает с душевным прискорбием на взаимные вражды и крамолы между разных народов, подвластных и подданных нашим высокостепенным ханам, сиятельному и превосходительному шамхалу Тарковскому и горским владельцам, существующие на раздоры и самовольные управы, разорение и опустошение за собою влекущие, на частые вооружения друг против друга, единою корыстию водимые, на самое низвержение ханов или горских владельцев с достоинств их, не имея на то законной власти; одним словом, на пагубные следствия, к истреблению рода человеческого клонящиеся, и что наконец нам, уполномоченным и доверенным, в лице наших высокостепенных ханов, сиятельного и превосходительного шамхала Тарковского и горских владетелей, созванных по сему предмету, всемилостивейше указать соизволил предложить постановления между собою твердого, непоколебимого и вечного, мирного и дружеского союза под верховным Е[го] И[мператорскаго] В[еличества] состоящих покровительством.

Вняв гласу сему милосердаго и человеколюбиваго о благе нашем и о благе общем Е[го] И[мператорскаго] В[еличества] попечения, с помощью Божиею и в присутствии вышеупомянутого Всероссийских войск ген[ерал]-л[ейтенанта], и разных орденов кавалера, кн[язя] Павла Цицианова, единогласно и единодушно постановили и заключили следующие статьи:

\section{Статья первая}

Превосходительный и высокостепенный Кубинский, владеющий ныне и Дербентом, Ших-Али хан, сиятельный и превосходительный Шамхал Тарковский, владетель Буйнацкий и Дагестанский Мегди, превосходительный и высокостепенный Талышинский Мир-Мустафахан, превосходительный и высокостепенный Каракайдакской округи владетель, Уцмий Рустем-хан, округи сей правитель, высокостепенный Рази-хан, превосходительный и высокостепенный Табасаранской округи владетель кади Рустем-хан и сей же округи высокопочтенные владельцы Сохраб-бек Маасум и Махмуд, удостоясь всемилостивейшего принятия в подданство и покровительство Е[го] И[мператорскаго] В[еличества] по собственным их просьбам, принесенным Всевысочай-

69 | Князь Павел Дмитриевич Цицианов представлял высшую российскую военную и гражданскую власть на Кавказе в 18021806 гг. частью оружием, частью путем дипломатических переговоров склонил к переходу на сторону России мусульманских владетелей по Каспийскому побережью Дагестана и Азербайджана. См. о нем: Лебедев, 1890. С.140-148. 
шему престолу Его, и получая всегда обильно Высокомонаршее Е[го] И[мператорскаго] В[еличества] к себе благоволение и великодушный о благе их промысел, пребудут навсегда непоколебимыми верноподданнической обязанности их Е[го] И[мператорскаго] В[еличества] и покровительству и защите всех их одною Всевысочайшею Державою E[го] И[мператорскаго] В [еличества], оставляя отныне впредь все бывшие до сего между ними вражды, несогласия, ссоры и неприязненные поступки, оставаясь все спокойными в своих владениях, в коих таковыми от Е[го] И[мператорскаго] В[еличества] всемилостивейшего защитника и покровителя их пожалованными их грамотами признаны, всемерно удерживать их будут за собою и ограждать их от неприятеля, принимая всегда заблаговременно надлежащие к тому меры. И для того соединяясь все бесконечно на предыдущие времена тесным союзом и дружбою, хранить будут оную свято, не дерзая никогда нападать на области своих союзников, и им подвластных ничем не оскорблять; в чем мы, яко уполномоченные и доверенные от них, и обязались вместо их присягою в присутствии выше именованного ген[ерал]-лейтенанта.

И, хотя превосходительный и высокостепенный Ших-Али-хан, оставшийся напоследок владетелем одной токмо Кубинской области, по разным стекшимся обстоятельствам и по разделу его с покойным братом его, Хасан-ханом ${ }^{70}$, всевысочайше E[го] И[мператорским] В[еличеством] утвержденному по смерти брата его и, приняв во владение свое гор[од] Дербент с принадлежащими к нему окрестностями, но в предупреждение всяких, иногда случиться могущих, посторонних на владение Дербентское посягательств, все, союзом сим и дружбою обязующиеся, решительно и единодушно признаем Ших-Али-хана дербентским ханом, с принадлежащими к городу сему окрестностями по $\mathrm{p}$ [еке] Самур и с принадлежащими к нему деревнями и улусами и других мест по праву наследства владетелем, по всемилостивейшим ему грамотам: по первой - блаженной памяти Г[осударя] И[мператора] Павла Петровича 71 - и по второй - подтвердительной, всемилостивейшего нашего государя и самодержца всероссийского Александра Павловича, в подданство, высокое покровительство и защиту принять удостоившего.

\section{Статья вторая}

А дабы таковая связь под верховным Е[го] И[мператорскаго] В[еличества] покровительством могла пребыть ненарушима между всеми союзниками сими, то в отвращение в самом начале причин, неудовольствие производящих, поставляем за правило себе в случае ка-

70 | Хасан-Хан - сын Фет Али-хана и брат Ших Али-хана, правил Дербентским ханством в 1796-1797 гг. После его смерти ханство перешло к Ших Али-хану. См.: Бутков, 1869. Ч. ІІ. С. 429; Бакиханов, 1991. С. 177.

71 | Павла I, правившего Российской империей в 1796-1801. 
ких-либо споров или ссор, не поступая между собою неприятельски, разбираться дружески, по общим законам и обыкновениям той земли, в которой то будет, как добрые соседи, без всякого пристрастия, через должное одного с другим сношение и объяснение; в трудных же или сомнительных случаях разбираться через посредника из ханов сего союза, кого сами за благо к тому признают пригласить, и чем оный посредник спор или неудовольствие решит, тем и удовольствоваться, делая должное по приговору его удовлетворение в претензии или ссоре. Когда же спорящимся будет сие не угодно, или по разногласию спор таковой решен быть не может, то, в таких случаях, относиться им на рассмотрение Е[го] И[мператорскаго] В[еличества], яко защитника и покровителя своего, и по повелениям его на то, повиноваться в полной мере, по верноподданнической их обязанности.

\section{Статья третья}

Персидские ханы и горские владельцы ${ }^{72}$, союзом сим и дружбою обязующиеся, установляют ненарушимо на предбудущие времена: в случае неприязненного на кого-либо из них нападения от присвояющих в Персии верховную власть быть всем к защите его готовыми и, яко добрые и искренние союзники, обязываются давать нужное по состоянию каждого войско и ополчаться единодушно всем к прогнанию общего их неприятеля; сверх же того обязуются не только таковым действием друг друга защищать, но и всякий неприязненный умысел, когда о том кто узнает, союзнику своему без упущения времени открывать. И, таким образом, составляя как бы едино тело и один народ, разделенный на разных правителей, под верховным Е[го] И[мператорскаго] В[еличества] покровительством и охранением состоящих, и приемля заблаговременно от замыслов неприятеля осторожность, всеми способами стараться оные отвращать и взаимно себя подкреплять, как добрым соседям пристойно и надлежит и как общая их и народов их безопасность того потребует. Войска же те, кои даваемы будут на вспоможение, по обычаям и правам, в пределах Персии и вообще у всех горских народах существующим, по то время, пока будут они надобны требующему помощи, должны быть на содержании его всем тем, что по обычаю на случай таковой следует, сверх же обычая ничего они требовать не должны и не могут. И все таковые вспомогательные войска должны состоять под главным предводительством того хана или владельца, которому они вспомогают против неприятеля его, а вместе с тем и собственного их, яко общих союзников. Впрочем, вспоможение такое в случае надобности друг другу обязуются делать действительно тем числом войска, которым в состоянии они будут, не уклоняясь от-

72 | К персидским ханам Азербайджана из участников Георгиевского договора относились Ших Али-хан Дербентский и Кубинский вместе с Мир Мустафой-ханом Талышинским. Остальные его участники объединены под названием «горских владельцев» Дагестана. 
нюдь от того ни под какими видами и ни для каких посторонних собственных их интересов, коль скоро получит от союзника своего уведомление постановить войско на вспоможение, во сколько они до просящего вспоможения хана или владельца дойти могут, полагая переходы на каждый день по 30-ти верст.

\section{Статья четвертая}

Сиятельный и превосходительный шамхал Тарковский, владетель Буйнацкий и Дагестанский, Мегди, превосходительный и высокостепенный Каракайдакской округи владетель, уцмий Рустем-хан, сей же округи правитель, высокостепенный Рази-хан, Табасаранской округи владетель, превосходительный и высокостепенный Кадий Рустем-хан и владельцы округи сей Сохраб-бек Маасум и Махмуд, сверх сего вышеписанного общего постановления их по сему союзу обязуются, что не токмо подвластным их отныне впредь строжайше запретят чинить какие-либо шалости, грабительства и обиды противу подданных союзных ханов, но, будучи и сами союзниками их, не попустят никогда ни на какие им неприязненности в угождение другим или из лакомства, и всегда и всемерно отводить от того будут и прочих соседственных им и необузданных Кавказа, Дагестана и прочих обитателей, преподавая им дружеский совет отнюдь того не делать, что доселе бывало, и не жертвовать собою и храбростию своею из найма в пользу злонамеренных союзных же ханов и подвластных им ни в чем не оскорблять, и тот постыдный свой промысел ${ }^{73}$ навсегда оставить, ежели хотят снискать себе какое-либо от всемилостивейшего покровителя и защитника их благоволение. В чем доверенные мы, особы, и дали от себя вместо их присягу.

\section{Статья пятая}

Союза сего ханы и владельцы, владения свои по берегу Каспийского моря имеющие, постановляют и обязываются следующим: буде крушение или гибель корабля или судна учинится по берегам Каспийскаго моря, то спасенные от крушения или гибели корабля или судна российского или персидского, как то: корабельные или судовые служители, купцы или иные люди мужеского или женского пола, товар или груз, судовые снасти и самый корабль, или судно, или часть оного, словом сказать, все, что спасено будет от гибели, да будет под Высочайшим E[го] И[мператорскаго] В[еличества] покровительством и защитою, и да не коснутся ни до чего противные какие-либо силы ${ }^{74}$. Всяк же верноподданный, наипаче сам владелец и старшины его, должны помогать

73 | Речь идет о набегах горских ополчений на владения соседей и на территорию Грузии.

74 | Грабеж потерпевших крушение у берегов Дагестана судов был одной из постоянных претензий Российской империи к дагестанским ханам, прежде всего к уцмию Кайтагскому, чьи подданные имели обыкновение заниматься этим промыслом. См.: [Броневский], 1996. C. 149. 
крушение или гибель терпящим людям и вещам, и да приложат крайнее старание о спасении корабля или судна и людей, товара или груза, и всего того, что только спасти можно; спасенное же со всяким попечением и тщанием да сбережется и сохранится в удобных и безопасных местах, дабы от худого смотрения или небрежения повреждено или истреблено быть не могло и да не присвоит себе никто ни малейшей части спасенного.

\section{Статья шестая}

Владелец должен немедленно объявить Е[го] И[мператорскаго] В[еличества] консулу или же ближайшего военного корабля или судна начальнику обо всем подробно, а ежели способнее будет доставить о несчастии том известие в Кизляр, тамошнему правлению, то посылать туда уведомление, и как можно скорее.

\section{Статья седьмая}

Всяк ко спасению корабля или судна и людей, товара или груза и ко сбережению и охранению способствующий, имеет право к получению награды за спасение и сбережение, буде не присвоил себе ни малейшей доли спасенного и объявил о том российскому консулу или военного какого судна начальнику, в персидских портах или городах находящемуся. Награда же за сбережение и спасение да будет (на всех, сколько бы их ни было) 4-я часть спасенного, буде кораблю, судну, или товару, или грузу, или оной, какой бы то ни было вещи учинилось на море, расстоянием от берега на версту; а буде на самом берегу учинилось несчастие людям или вещам, то 6-я часть спасенного; и сию 4-ю или 6-ю часть разделить на 4 доли: две доли отдать людям, кои спасли из воды спасенное, одну долю отдать людям, кои сберегли спасенное, и одну долю отдать начальнику тому, кто распоряжал спасение и сбережение. Спасение же людей да будет безденежно из одного человеколюбия.

\section{Статья восьмая}

Купеческий торг при персидских портах, союзникам принадлежащих, исключая пошлинного с товаров сбору, остается на прежнем положении. Пошлину же с товаров (по примеру тому, как берется она при порте Бакинском) отныне впредь определяют они следующую, и именно: с таи или связки шелку, из шести пуд состоящей, 1 р[убль] 70 к[опеек], с таи сукна - 5 р[ублей] 22 к[опеек]; с бочки семени канцелярного, до 6 пудов содержащей онаго, также 5 р[ублей] 22 к[опеек]; с бочки олова - 2 р[убля] 40 к[опеек]; с мешка брусковой краски, 6 пудов - 5 р[ублей] 22 к[опеек]; с 20 пудов железа 
полосного - 25 к[опеек]; с таи бумаги писчей -1 р[убль] 5 к[опеек]; с таи холста - 2 р[убля] 89 к[опеек]; с таи порты - 2 р[убля] 40 к[опеек]; с мешка чернильных орехов и марены в 8 пудов 20 к[опеек]; с таи парчевого товару, также и с таи бурметей или бязи 1 р[убль] 7 к[опеек]; с сундука с товарами стальными и железными или с чем бы то ни было - 1 р[убль] 27 к[опеек]; с ящика свечь 60 к[опеек]; да и со всех прочих вещей и товаров, каковые сверх вышеписанного означения в привозе будут, собирать пошлину при всех портах одинаковую, без малейшего излишества.

\section{Статья девятая}

Сухопутную купечествующих людей торговлю обеспечить наилучшим образом; и для того обязывается каждый союзный хан и владелец пешись всемерно о безопасном проезде караванов и купцов чрез его владение. И потому каждое селение, в окружности коего случится грабеж или разбой, отвечает за случай таковой полным и немедленным удовлетворением ограбленных купцов или вощиков товарных и наказывают грабителей и разбойников по вине их без малейшего послабления или снисхождения, по установлениям, на случай таковой у них существующим. В случае же медленности в удовлетворении таковом обиженных, по обстоятельствам встретиться могущим, сам хан или владелец, в чьем владении грабеж и разбой случится, собственностию своею удовлетворить обязан в полной мере пограбленному или отнятому, себе же после получает удовлетворение с виновника, который, по изысканию его, найдется, и наказывает его за то по вине его, как выше сказано.

\section{Статья десятая}

Российским купцам, армянам, грузинам и других сословий людям, право купечества имеющим, подданным Е[го] И[мператорскаго] В[еличества], производящим торги свои в пределах владения союзников, да ни посягнет никто ни на малейшую обиду и требование от него излишнего, сверх установлений. Купечеству таковому и всякого звания подданным России, проезжающим через владения союзных ханов и владельцев, обязан всяк союзник своею защитою и покровительством. Относительно же купечества, сим союзникам принадлежащего, торги свои в пределах России производящего, и подданных и подвластных им людей, по надобности в Россию приезжающих, все вообе союза сего ханы и владельцы, яко подданные Е[го] И[мператорскаго] В [еличества] и покровительствуемые Им всемилостивейше, видев многие уже опыты, надеются, что покровительство и защита всегда в полной мере будет по Всевысочайшим Е[го] И[мператорскаго] В[еличества] законам, и для того, в случае надобности, по делам купечества их и прочего под- 
данного и подвластного им народа остаются они на прежнем основании в сношениях их с пограничным Кавказского края начальником.

\section{Статья одиннадцатая}

Постановление сие на дружеский союз делается на вечные времена. И для того всякий преемник владения в союз сей входящих персидских ханов и горских владельцев, на что должен он иметь Всевысочайшее от Е[го] И[мператорскаго] В[еличества] утверждение, яко от всемилостивейшего покровителя и защитника союзу сему, на самой истине обязан поступать во всем по сим постановлениям.

\section{Статья двенадцатая}

Нарушитель дружеского сего на союз постановления подвергается строжайшему наказанию. И для того прочие союзники нарушение таковое с истинными на то доказательствами должны предать всемилостивейшему Е[го] И[мператорскаго] В[еличества] благоусмотрению через пограничного здешнего начальника и Всевысочайшую по тому волю выполнить в самой точности. В прочем буде в продолжении времени по общим их согласиям усмотрено будет еще что-либо за лучшее к безопасности и распространению торговли, к пользе союзников, к благосостоянию и спокойствию самих их и подданного и подвластного им народа, поднесется всеподданнейше через означенного же здешнего края начальника на Высочайшее Е[го] И[мператорскаго] В[еличества] утверждение.

В удостоверение чего мы, нижеподписавшиеся доверенные, по довериям нам от владетелей наших подписали сии статьи и приложили к ним свои печати на Кавказской линии в г. Георгиевск, декабря 26-го дня 1802 г.

\section{Клятвенное обещание}

Мы, нижеименованные, доверенные на постановление дружеской связи, особы 3-го класса75: Кубинского и Дербентского Ших Алихана чиновник его Медет-бек; ген[ерал]-л[ейтенанта] Мегди, шамхала Тарковского, владетеля Буйнацкого и Дагестанского чиновник его Мирза-бек; ген[ерал]-л[ейтенанта] Талышинского Мир-Мустафа-хана двоюродный брат его Мирза-Мамед бек; 4-го класса76 уцмия каракайтахского Рустем-хана чиновник его Ахмед-ага; 4-го же класса Таба-

75 | Согласно Табели о рангах после вступления в российское подданство шамхалу Тарковскому, хану Дербентскому и Кубинскому, хану Талышинскому было присвоено воинское звание генерал-лейтенанта, что соответствовало 3-му классу или тайному советнику гражданской службы.

76 | По той же Табели о рангах уцмий Кайтагский, кади, майсум и два независимых владетеля Табасаранских были вовзведены в 4-й класс, получив воинское звание генерал-майора, соответствующее гражданскому действительному тайному советснику. 
саранского округа владельца Рустем-кадия чиновник его Мамед-бек; высокостепенного Рази-хана, правителя области Каракайтахской, чиновник его Узней-бек и табасаранских владельцев Сохраб-бек маасума, Нур-Мамед-ага Мустафаев и Махмуда - Ших-мулла, даем сие клятвенное обещание пред Всемогущим Богом, великим пророком нашим Мухаммедом и святым его Кораном, именем владетелей наших, яко доверенные от них, что по восстановлении между означенными владетелями нашими навсегда доброй дружеской связи, отныне, впредь, оставят они всякую между ими вражду и неприязненные поступки, и оставаясь все спокойными в своих владениях, в коих таковыми от всемилостивейшего их Гсударя и Самодержца Всероссийского, в подданство, в высокое покровительство, в защиту принять их удостоившего, пожалованными им грамотами признаны. Для удержания за собою тех владений и для ограждения их от неприятеля принимать всегда будут надлежащие меры, соединенную ими союзом дружбу хранить будут ненарушимо свято, не дерзнут никогда нападать на области своих союзников и не посягнут никогда, ни под каким видом, на оскорбление подвластных их.

И в заключение сей клятвы нашей целуем книгу святой Коран ${ }^{77}$ и во оном страшные слова. Аминь, декабря 26-го дня 1802 г.

[РФ ИИАЭ. Ф. 1. Оп. 1. Д. 551. Л. 1978.]

(Перевод с арабского языка, современный оригиналу. Копия.)

77 | Согласно общим нормам договоров и делопроизводства на мусульманском Востоке для мусульманских владетелей и их подданных, перешедших под власть Российской империи, была учреждена присяга на Коране, широко применявшаяся на Кавказе в XIX в. 78 | Опубликовано с сокращ. в кн.: Дубровин, 1866. С. 485-491; полный текст в изд.: АКАК. Т. II. 1868. С. 1010-1012; Русскодагестанские отношения, 1988. С. 258-263. 


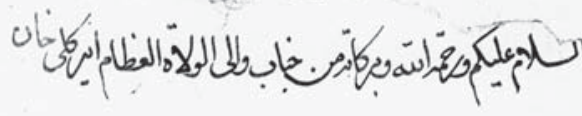

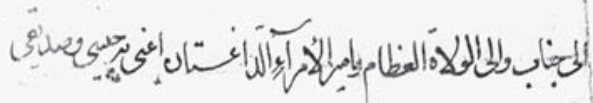

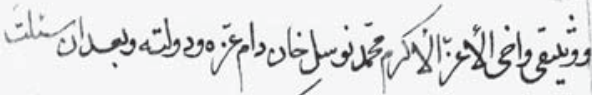

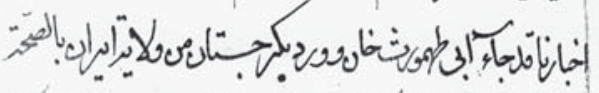

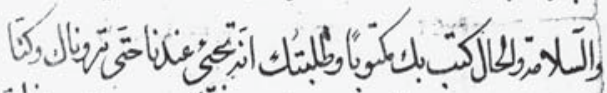

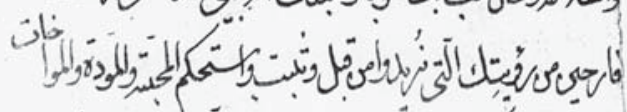

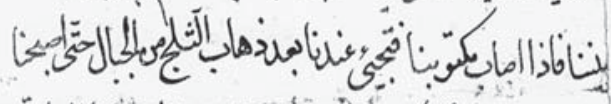

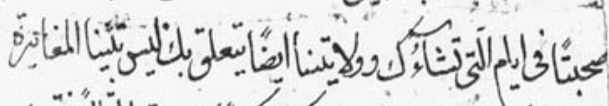

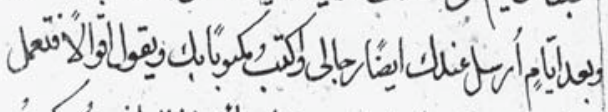

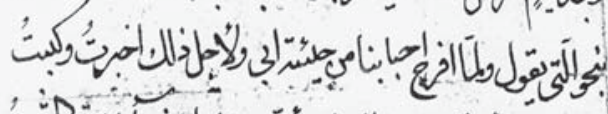

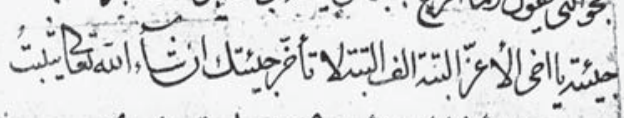

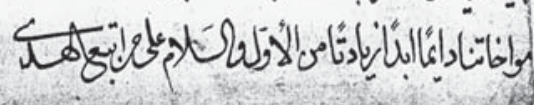

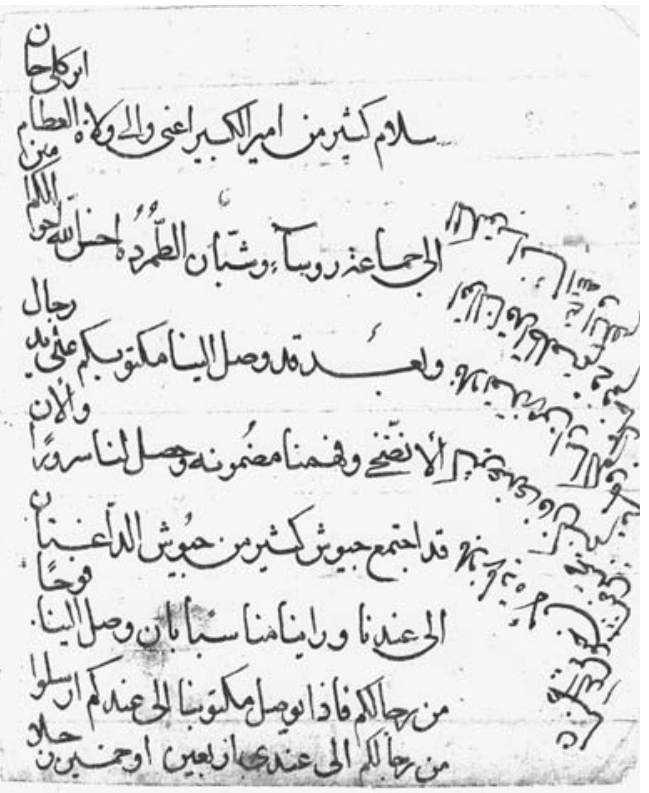




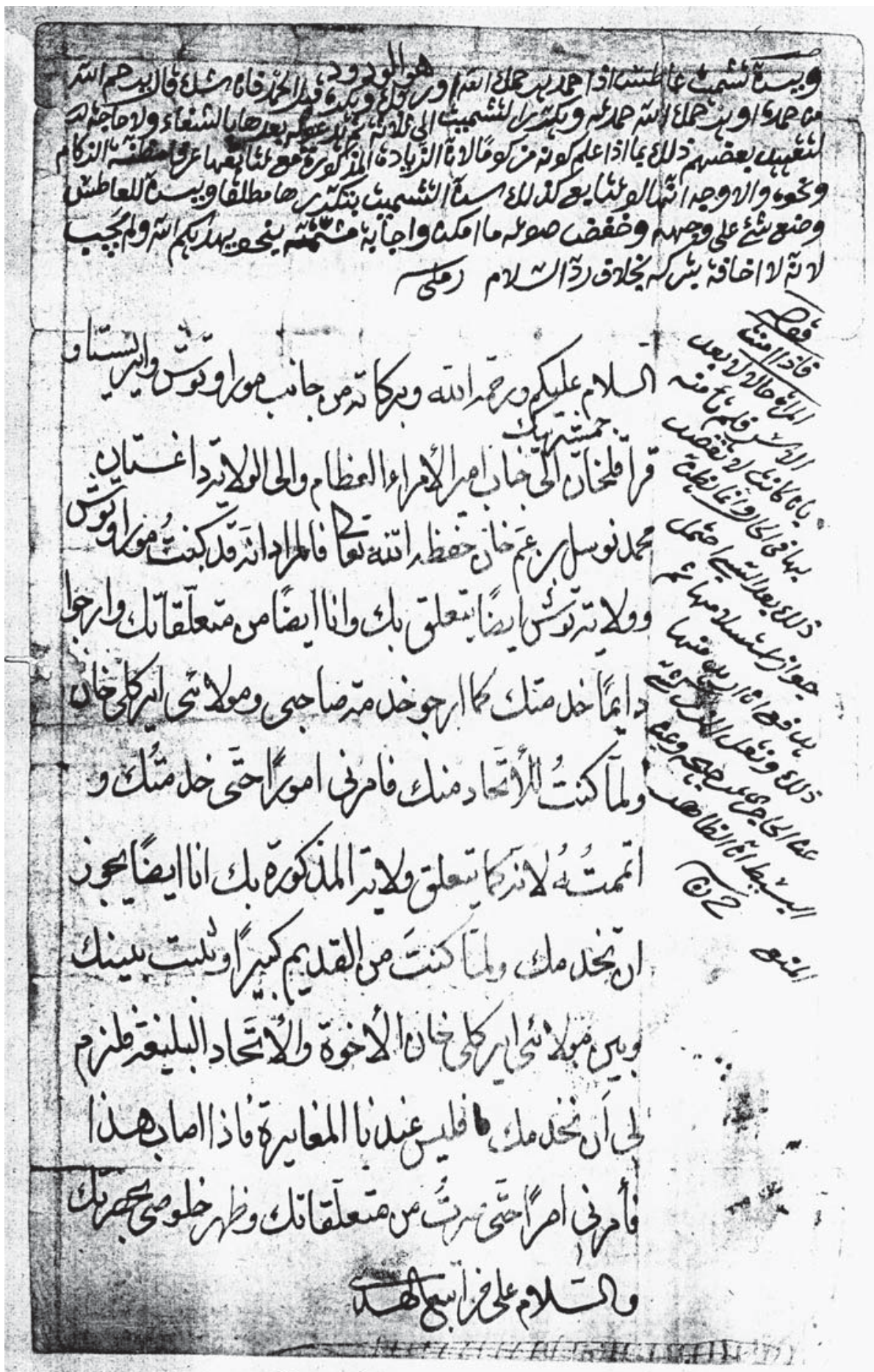




\section{Список сокращений}

АКАК - Акты, собранные Кавказской археографической комиссией / Под ред. А.П. Берже. Т. ІXII. Тифлис, 1868-1904.

РФ ИИАЭ - Рукописный фонд Института истории, археологии, этнографии Дагестанского научного центра Российской академии наук. Махачкала. 


\section{Источники и литература}

Айтберов, 1986 - Айтберов Т.М. Материалы по хронологии и генеалогии правителей Аварии // Источниковедение средневекового Дагестана. Махачкала, 1986.

Алиев, Умаханов, 1999 - Алиев Б.Г., Умаханов М.-С.К. Историческая география Дагестана XVII - начала XIX в. Кн. І. Махачкала, 1999.

АКАК. Т. ІІ. 1868 - Акты, собранные Кавказской археографической комиссией / Под ред. А.П. Берже. Т. II. Тифлис, 1868.

Бакиханов,1991 - Бакиханов А-К.-А. Гюлистан-и Ирам / ред., комм., примеч., указатели 3.М. Буниятова. Баку, 1991.

[Броневский], 1996 - [Броневский С.М.] Исторические выписки о сношениях России с Персиею, Грузиею и вообще с горскими народами, на Кавказе обитающими со времен Ивана Васильевича доныне / Подгот. текста И.К. Павловой. СПб., 1996.

Бутков, 1869 - Бутков П.Г. Материалы для новой истории Кавказа (1722-1803). Ч. II-III. СПб., 1869.

Гамрекели, 1991 - Гамрекели В.Н. Межкавказские политические и торговые связи Восточной Грузии (конец 60-х - начало 90-х годов XVIII в.): документы и материалы. Вып. II. Тб., 1991.

Георгиевский трактат, 1983 - Георгиевский трактат: Договор 1783 года о вступлении Восточной Грузии под покровительство России / Текст подгот. к изд., введ. и примеч. снабд. Г.Г. Пайчадзе. Тбилиси, 1983.

Дмитриев, 2009 - Дмитриев В.А. Отношение к пространству и времени в культуре народов Северного Кавказа. СПб., 2009.

Договоры с Востоком, 1869 - Договоры с Востоком политические и торговые / Собр. и изд. Т. Юзефович. СПб., 1869.

Дубровин, 1866 - Дубровин Н.Ф. Закавказье от 1803-1806 гг. СПб., 1866.

Дубровин, 1888 - Дубровин Н.Ф. История войны и владычества русских на Кавказе. Т. VI. СПб., 1888.

Карпов, 2001 - Карпов Ю.Ю. Россия и этносоциальные процессы на Северном Кавказе в новое и новейшее время // Россия и Кавказ сквозь два столетия / Сост. и ред. Г.Г. Лисицына, Я.А. Гордин. СПб., 2001.

Карпов, 2007 - Карпов Ю.Ю. Взгляд на горцев, взгляд с гор. Мировоззренческие аспекты культуры и социальный опыт горцев Дагестана. СПб., 2007.

Каштанов, 1999 - Каштанов С.М. 0 титуле московских государей в XV-XVIII вв. // Россия в IX-XX вв.: проблемы истории, историографии и источниковедения. М., 1999.

Козлова, 1988 - Козлова А.Н. 0 коллекции писем на персидском языке на имя Умма-хана Аварского // Изучение истории и культуры Дагестана: археографический аспект. Махачкала, 1988.

Лавров, 1968 - Лавров Л.И. Эпиграфические памятники Северного Кавказа на арабском, персидском и турецком языках. Ч. 2. Надписи XVIII-XX вв. М., 1968. 
Лавров, 1968 - Лавров Л.И. Этнография Кавказа. Л., 1982. С. 148.

Лебедев, 1890 - Лебедев П.С. Князь Павел Дмитриевич Цицианов // Русская старина. 1890. Т. 66. № 4.

Материалы по истории русско-грузинских отношений, 1988 - Материалы по истории русско-грузинских отношений второй половины XVIII века. Ч. 3. Тб., 1988.

Норденстам, 1958 - Норденстам И.И. Описание Антль-Ратля // История, география, этнография Дагестана в XVIII-XIX вв.: архивные материалы / Под ред. Х.-М.О. Хашаева. М., 1958.

Петрушевский, 1934 - Петрушевский И.П. Джаро-Белоканские вольные общества в первой половине XIX в. Тифлис, 1934.

Пчелов, 2008 - Пчелов Е.В. Объектный титул русских государей: особенности структуры и принципы формирования // Вспомогательные исторические дисциплины - источниковедение - методология истории в системе гуманитарного знания. Материалы XX Международной научной конференции. Ч. І. М., 2008.

Русско-дагестанские отношения, 1988 - Русско-дагестанские отношения в XVIII - начале XIX в.: Сборник документов / Отв. ред. В.Г. Гаджиев. М., 1988.

Северный Кавказ в составе Российской империи, 2007 - Северный Кавказ в составе Российской империи / Отв. ред. В.О. Бобровников, И.Л. Бабич. М., 2007.

Филюшкин, 2008 - Филюшкин А.И. Титулы русских государей. М.- СПб., 2006.

Хроника войн Джара, 1931 - Хроника войн Джара в XVIII столетии / Пер. П.К. Жузе с предисл. В. Хулуфлу. Баку, 1931.

Pollock, 2006 - Pollock S. "Empire by Invitation"? Russian Empire Building in the Caucasus in the Reign of Catherine II. Ph. D. Dissertation. Harvard University: Boston, 2006.

Süleymenova, 1997 - Süleymenova S.A. XVIII əsr Azərbaycan tarixinə dair məsələlərin ərəbdili yerli mənbələrdə işiglandirilmasi // AMEA-nın xəbərləri. Baki, 1997. 